
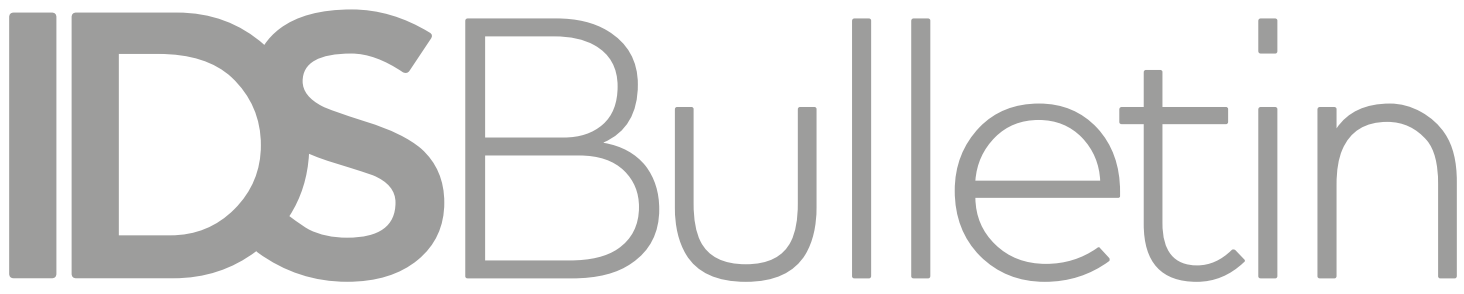

Transforming Development Knowledge

ARCHIVE COLLECTION

Volume 51 | Number 1A | May 2020

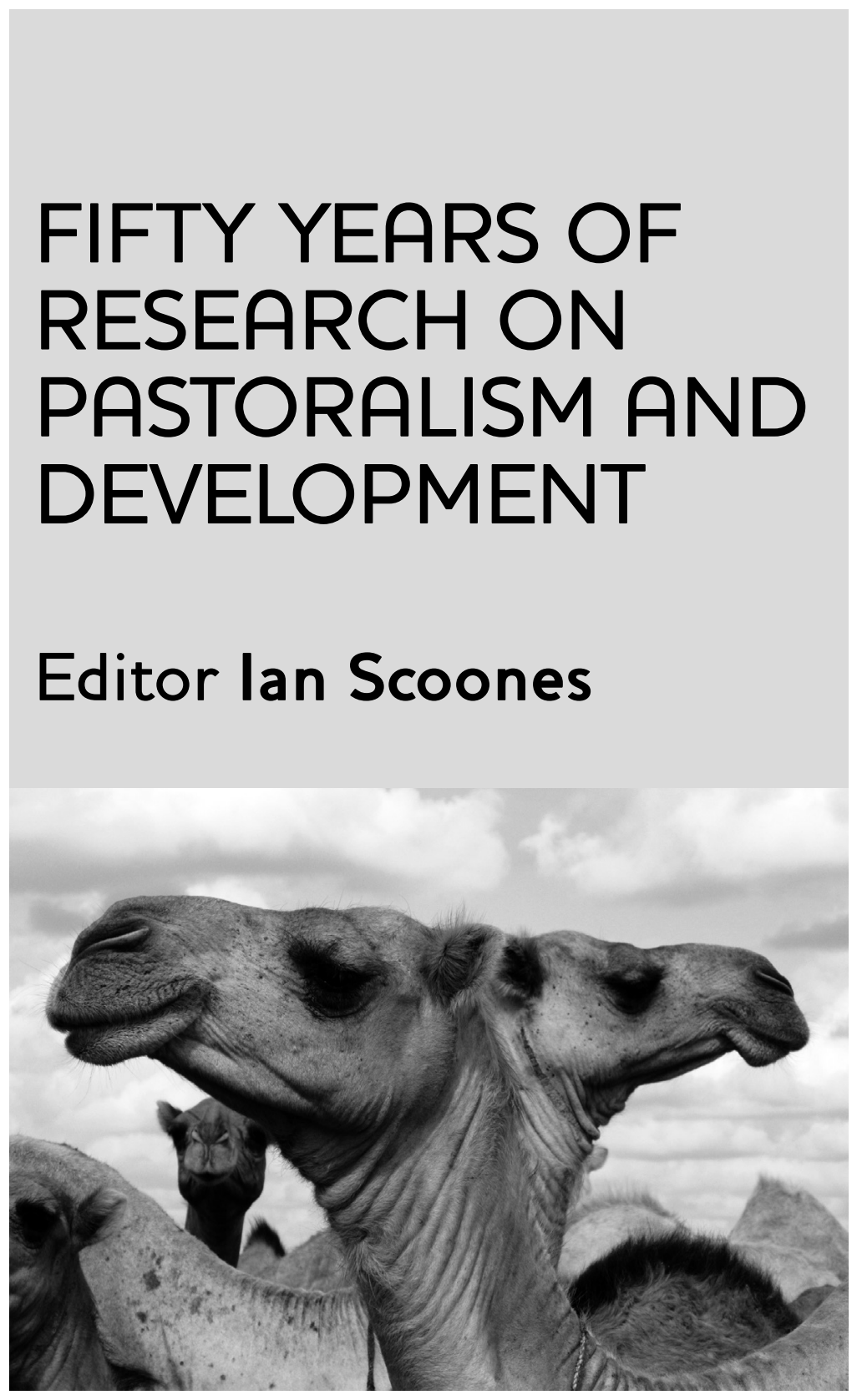




\section{Contents}

Pastoralism and Development: Fifty Years of Dynamic Change lan Scoones, Jeremy Lind, Natasha Maru, Michele Nori, Linda Pappagallo, Tahira Shariff, Giulia Simula, Jeremy Swift, Masresha Taye and Palden Tsering

Article first published May 2020, IDSB51.1A

\section{PASTORAL LIVELIHOODS}

Access to Food, Dry Season Strategies and Household Size amongst the Bambara of Central Mali

Camilla Toulmin

Article first published July 1986, IDSB17.3

Gender and Livelihoods in Northern Pakistan

Susan Joekes

Article first published January 1995, IDSB26.1

\section{INSTITUTIONS AND COMMON PROPERTY RESOURCE MANAGEMENT}

Local Customary Institutions as the Basis for Natural Resource Management Among Boran Pastoralists in Northern Kenya

Jeremy Swift

Article first published October 1991, IDSB22.4

Institutional Change in the Syrian Rangelands

T. Ngaido, F. Shomo and G. Arab

Article first published October 2001, IDSB32.4

\section{CLIMATE CHANGE AND ECOLOGICAL DYNAMICS}

Climate Change and the Challenge of Non-equilibrium Thinking

lan Scoones

Article first published July 2004, IDSB35.3

Pastoralists, Patch Ecology and Perestroika: Understanding Potentials for Change in Mongolia

Robin Mearns

Article first published October 1991, IDSB22.4

\section{FOOD SECURITY, EARLY WARNING, AND LIVELIHOOD VULNERABILITY}

Why are Rural People Vulnerable to Famine?

Jeremy Swift

Article first published May 1989, IDSB20.2

Food Security: Let them Eat Information

Margaret Buchanan-Smith, Susanna Davies and Celia Petty

Article first published May 1994, IDSB25.2 


\section{PASTORAL MARKETING}

Communities, Commodities and Crazy Ideas: Changing Livestock Policies in Africa Andy Catley, Tim Leyland, Berhanu Admassu, Gavin Thomson, Mtula Otieno and Yacob Aklilu Article first published June 2005, IDSB36.2

Youth Participation in Smallholder Livestock Production and Marketing Edna Mutua, Salome Bukachi, Bernard Bett, Benson Estambale and Isaac Nyamongo Article first published May 2017, IDSB48.3

\section{CONFLICT AND GOVERNANCE}

\section{Reconstructing Political Order Among the Somalis: The Historical Record in the} South and Centre

David K. Leonard and Mohamed Samantar

Article first published January 2013, IDSB44.1

Livestock Raiding Among the Pastoral Turkana of Kenya: Redistribution, Predation and the Links to Famine

Dylan Hendrickson, Robin Mearns and Jeremy Armon

Article first published July 1996, IDSB27.3

Conflict Management for Multiple Resource Users in Pastoralist and Agro-Pastoralist Contexts

Ben Cousins

Article first published July 1996, IDSB27.3 


\section{Erratum}

There were typographic errors in Table 1 on page 47 of Leonard, D.K. and Samantar, M. 'Reconstructing Political Order Among the Somalis: The Historical Record in the South and Centre', IDS Bulletin 44.1.

The table was published as follows in the original publication.

\begin{tabular}{|c|c|c|c|c|c|c|c|}
\hline \multirow[t]{2}{*}{ No. } & \multirow[t]{2}{*}{ Region } & \multicolumn{6}{|c|}{ Percentages of participation } \\
\hline & & $\begin{array}{l}\text { Reg. auth. } \\
\text { or pols }\end{array}$ & $\begin{array}{l}\text { Reg. auth. } \\
\text { only }\end{array}$ & Islamic & Diaspora & Interntl & $\begin{array}{l}\text { Sub-clan } \\
\text { Leaders } \\
\text { (isimo) }\end{array}$ \\
\hline 93 & ALL 10 & 48 & 40 & 26 & 5 & 17 & 16 \\
\hline 28 & All '95-'04 & 39 & 32 & 36 & 11 & 7 & 21 \\
\hline 9 & Hiraan & & 11 & 22 & 89 & & \\
\hline 8 & Mudug and Galguduud & 50 & 50 & 25 & 25 & & \\
\hline 5 & Shabeele Dhexe & 80 & 20 & 100 & 60 & 60 & \\
\hline 10 & Shabeele Hoose & & 100 & & & & \\
\hline 10 & Jubba Dhexe & 50 & 30 & 10 & & & \\
\hline 25 & Jubba Hoose & 76 & 72 & 4 & 36 & & \\
\hline 12 & Gedo & 100 & 92 & 17 & 33 & 17 & 25 \\
\hline 14 & Bay and Bakool & 29 & 14 & 43 & 7 & 14 & \\
\hline
\end{tabular}

The table has been amended for publication in the Archive Bulletin issue Scoones, I. (ed.) (2020) 'Fifty Years of Pastoralism at IDS', IDS Bulletin 51A.

It now reads as follows.

\begin{tabular}{|c|c|c|c|c|c|c|c|}
\hline \multirow[t]{2}{*}{ No. } & \multirow[t]{2}{*}{ Region } & \multicolumn{6}{|c|}{ Percentages of participation } \\
\hline & & $\begin{array}{l}\text { Reg. auth. } \\
\text { or pols }\end{array}$ & $\begin{array}{l}\text { Reg. auth. } \\
\text { only }\end{array}$ & Islamic & Diaspora & Interntl & $\begin{array}{l}\text { Sub-clan } \\
\text { Leaders } \\
\text { (isimo) }\end{array}$ \\
\hline 93 & ALL 10 & 48 & 40 & 26 & 5 & 17 & 16 \\
\hline 28 & All '95-'04 & 39 & 32 & 36 & 11 & 7 & 21 \\
\hline 9 & Hiraan & & & 11 & & 22 & 89 \\
\hline 8 & Mudug and Galguduud & 50 & 50 & 25 & & 25 & \\
\hline 5 & Shabeele Dhexe & 80 & 20 & 100 & & 60 & 60 \\
\hline 10 & Shabeele Hoose & & & 100 & & & \\
\hline 10 & Jubba Dhexe & 50 & 30 & & 10 & & \\
\hline 25 & Jubba Hoose & 76 & 72 & 4 & & 36 & \\
\hline 12 & Gedo & 100 & 92 & 17 & 33 & 17 & 25 \\
\hline 14 & Bay and Bakool & 29 & 14 & 43 & & 7 & 14 \\
\hline
\end{tabular}




\title{
Reconstructing Political Order Among the Somalis: The Historical Record in the South and Centre
}

\author{
David K. Leonard and Mohamed Samantar
}

Abstract The reconstruction of a larger polity in a violence-torn society such as Somalia requires negotiation of a new social contract between the superordinate body and the local units of governance that have provided citizens some degree of order throughout the conflict. In this article we show that the very different trajectories for state-building in the north and south of the country result in good part from different attention to this generalisation. The founding leaders in Somaliland and Puntland consulted extensively with the assemblies of elders and were able to create civilian constitutional orders. Military leaders in the south and central regions did not incorporate their elders into their political systems, even though they controlled similar amounts of territory to their counterparts in the north. Ultimately various Islamic movements did build on community-level governance and used it to successfully challenge the old 'warlords' but most of those allied with the Transitional Federal Government remain weak at the community base.

\section{The dual social contract}

Even though Somalia was composed of stateless societies before colonialism and much of the country has returned to that condition today, it did and does possess local systems of governance that provide social order (Leonard and Samantar 2011). With the collapse of the national government of Somalia that followed the successful revolution in 1991 against then President Siad Barre, the commercial centres, ports and trading routes from which revenues could easily be extracted fell under the control of militias organised by former army officers and their business allies. Although clan governance had been greatly weakened by Italian colonialism and was not important (at least among elites) in the major urban areas, it began to reappear as a principle of social organisation as Barre's government weakened in the 1980s. As the fighting for territorial control deepened after 1991, all the 'warlords' and businessmen came to base their alliances on sub-clan affiliations. For example, General Mohamed Said Hersi 'Morgan' (who ultimately came to control Kismaayo) initially was allied with other officers of the Ogaden sub-clan even though he was Harti, but ultimately he formed a Harti sub-clan alliance.
Similarly, at the community level people reinforced their sub-sub-clan affiliations and relied primarily on their 'diya-paying' groups ${ }^{1}$ to assure their protection. Even though the elite level of militia organisation and the communitylevel of mutual protection both were based on segmentary patrilineages, the two did not always have close relationships.

We have argued elsewhere (Leonard and Samantar 2011) that the legitimacy of a post-conflict state in contemporary Africa relies on two social contracts one within the community and another between it and the larger state. Traditionally social contract theorists (from Hobbes through Rawls) have used the idea of an imaginary social contract to argue about when and whether citizens should obey their state, in other words, whether they should accord it legitimacy. In contemporary discussions about Africa, however, the idea of the social contract has also come to include whether or not people actually $d o$ feel an obligation to their rulers and what they expect from them in return. The colonial state was based on the legitimacy inhabitants gave to their local systems of governance and then the bargain that was made between that 'traditional' order and the state itself - in other words a dual social 
contract. Mamdani (1996) has highlighted the importance of this two-tiered system of order in rural Africa. It is our observation that during periods of civil violence a similar dual contract is evident in the urban areas as well, with communities segregating along ethnic lines and choosing leaders (who are not necessarily traditional) to enforce internal order and mediate conflicts with other groups (see Mushi, this IDS Bulletin).

A second aspect of local governance beyond the sub-sub-clan and the diya-paying group is evident as well among the Somalis - the Islamic Sharia court. Somalis are gifted traders and devout Muslims. Throughout the period of their civil wars they have relied heavily on local Sharia courts to resolve their commercial and family disputes. These courts are rooted in the local community and in Somaliland and Puntland they are supported by the state/regional government as well. In the southern and central regions of Somalia, however, the 'warlords' failed to incorporate either the local elders or the Sharia courts into a governance order. This double neglect left them vulnerable to the Islamic Court Union and its successors when they developed in the early twenty-first century. The different strategies and trajectories of Somaliland and Puntland, on the one hand, and the 'warlords' of the south and centre of the country, on the other, is the story to which we now turn. (For a full development of the arguments in this section and the evidence supporting them, see Leonard and Samantar 2011).

\section{The transitions in Somaliland and Puntland}

Somaliland and Puntland followed similar routes from being 'liberated' territories to the reconstruction of state structures and their stories have been well told elsewhere (Bradbury 2008; Mohamed and Nur 2008). Both regions were early in giving birth to exiled, clan-based movements in opposition to the Barre government and these parties quickly assumed local leadership after its fall in 1991. But the important point in terms of their ultimate stability and legitimacy is that in both cases the new systems of governance were validated and shaped through extensive, locally led processes of consultation with citizen assemblies of elders and their representatives (isimo).

Somaliland was proclaimed very quickly as an independent entity by an assembly of elders meeting at Burco on 18 May 1991. The consolidation of its governance structures took another two years of wide consultation, however. This led in 1993 to the formal appointment of sub-clan representatives to a national legislature and the selection as president of Mohamed Ibrahim Egal, who had been a prime minister of Somalia in the 1960s and initially had opposed Somaliland's return to separate independence. The new constitution of Somaliland provided for a two-house legislature. The 'upper', consultative, house is comprised of the founding leaders and representatives (isimo) of the elders. The 'lower', dominant, house was initially comprised of representatives selected by sub-clan assemblies of elders (who in the case of the Somalis are all adult males) but is now chosen by election.

The movement that established itself in power in Puntland had long been led by Abdulaahi Yusuf Ahmed, who had served in the Somali army before going into exile. After militarily expelling an Islamist extremist group in 1992, he became the dominant figure in the region. The incorporation of elders into the support base for his regime came later than in Somaliland, although it similarly involved extensive consultations. Puntland declared itself an autonomous region within the (non-functional) state of Somalia in 1998 and its Council of Elders, as the unicameral legislature, confirmed Ahmed as its president. There was fighting when Ahmed had his term as president extended in 2001, but the Council of Elders (which is still selected from the base by local assemblies of elders, rather than elected) remains a key part of Puntland's governance structure.

The foregoing sketches miss an important qualification, however, one that speaks still further to the importance of local governance. The administrative regions of Sanaag and Sool lie at the boundary of Somaliland and Puntland and are contested between them. They were parts of British Somaliland and on that basis are claimed by present-day Somaliland. Clan-wise, however, they are Darood and thus more naturally a part of Puntland, which also claims them. The residents of the regions have appointed different sets of senior elders who separately are accepted as representatives by each of the two proto-states (Hoehne 2011). These appointments of isimo are politicised and influenced by the governments of Puntland and Somaliland, but their centrality illustrates both the dependence of local 


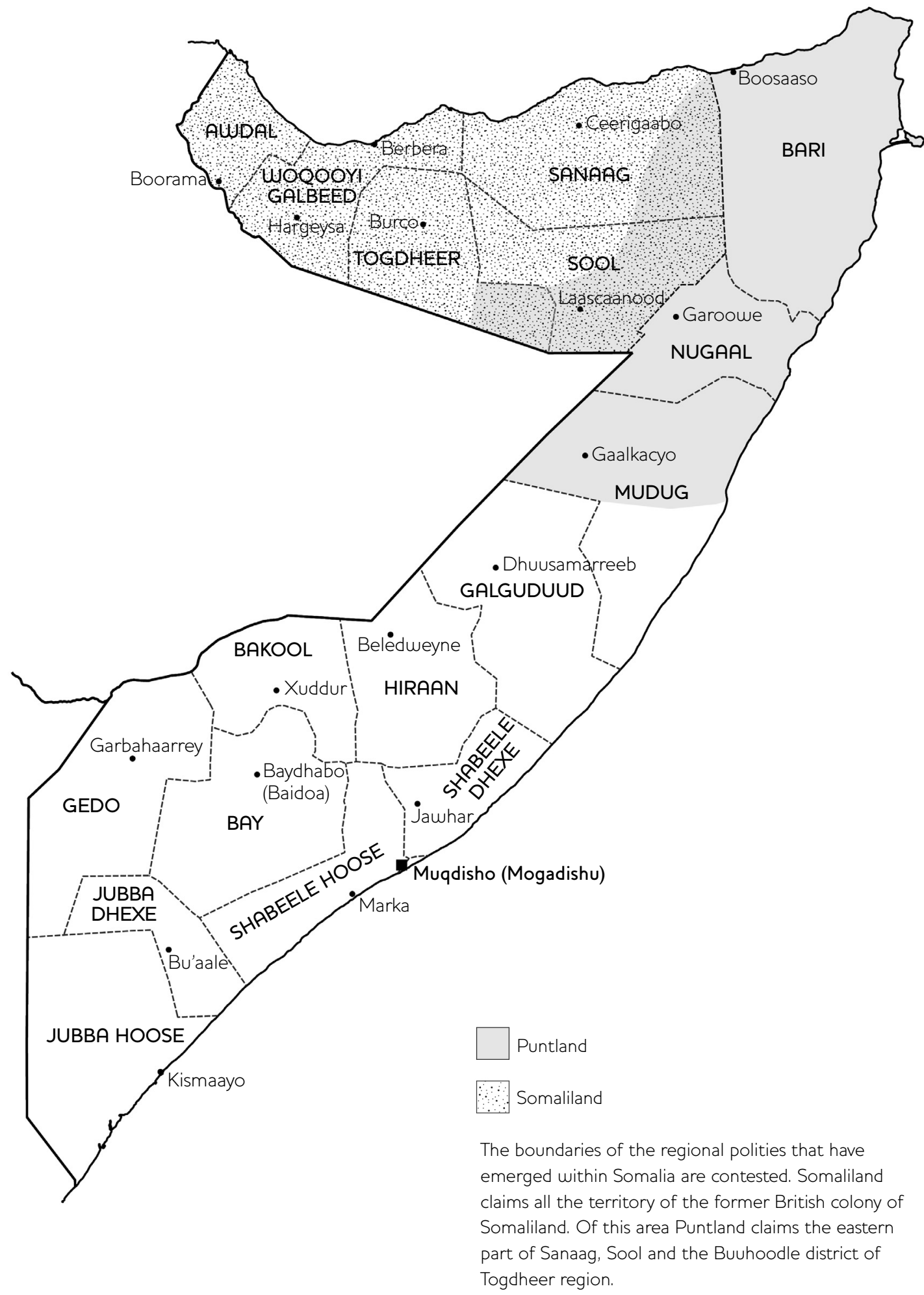

Redrawn from United Nations Map 3690 Rev 10. 


\begin{tabular}{|c|c|c|c|c|c|c|c|}
\hline \multirow[t]{2}{*}{ No. } & \multirow[t]{2}{*}{ Region } & \multicolumn{6}{|c|}{ Percentages of participation } \\
\hline & & $\begin{array}{l}\text { Reg. auth. } \\
\text { or pols }\end{array}$ & $\begin{array}{l}\text { Reg. auth. } \\
\text { only }\end{array}$ & Islamic & Diaspora & Interntl & $\begin{array}{l}\text { Sub-clan } \\
\text { Leaders } \\
\text { (isimo) }\end{array}$ \\
\hline 93 & ALL 10 & 48 & 40 & 26 & 5 & 17 & 16 \\
\hline 28 & All '95-'04 & 39 & 32 & 36 & 11 & 7 & 21 \\
\hline 9 & Hiraan & & & 11 & & 22 & 89 \\
\hline 8 & Mudug and Galguduud & 50 & 50 & 25 & & 25 & \\
\hline 5 & Shabeele Dhexe & 80 & 20 & 100 & & 60 & 60 \\
\hline 10 & Shabeele Hoose & & & 100 & & & \\
\hline 10 & Jubba Dhexe & 50 & 30 & & 10 & & \\
\hline 25 & Jubba Hoose & 76 & 72 & 4 & & 36 & \\
\hline 12 & Gedo & 100 & 92 & 17 & 33 & 17 & 25 \\
\hline 14 & Bay and Bakool & 29 & 14 & 43 & & 7 & 14 \\
\hline
\end{tabular}

administration on the elders and their role in mediating potentially dangerous conflicts between larger political entities.

The northern regions of Somalia thus clearly affirm the conclusion (Gundel and Dharbaxo 2006) that

the traditional leaders in Somalia are not only the prime force for stability and continuity in terms of regulating access to pastures, water and conflict resolution between clans but also, especially in Somaliland and Puntland, have been instrumental in establishing relatively stable structures of governance, jurisprudence and security.

\section{The other Somali transitions}

Why was the pattern of state reconstruction in the south and centre of Somalia so very different from what we observe in the north? Gundel and Dharbaxo 2006), whom we have just quoted, continue:

The traditional structures in South Central Somalia are different and more composite, fragmented, weakened and confused than in the north, for a range of reasons:... [a] heterogeneous mix of... people... the colonial experience is different... the dynamics of the civil war in the south differed as well, resulting in an equally different impact on the traditional structures. Hence, the common attempts to superimpose, or project the welldescribed northern traditional structures upon the societies in the south are wrong.
We submit that this statement is partly correct while also missing a critical aspect of the sad political trajectory in the south. It certainly is true that the capital, Mogadishu (located in South Central Somalia), ${ }^{2}$ was such a valuable commercial prize and had such a diverse clan demography that there was little prospect that it could have been handled through the northern pattern of relatively consensual consultations of clan isimo and gatherings of elders. But even the southern port of Kismaayo is no more ethnically homogeneous or commercially valuable than the Somaliland port of Berbera and the Puntland port of Boosaaso. It is true that the inter-riverine area around Baidoa incorporates intertwined clans involved in distinct livestock and crop production systems (with the latter much more easily disrupted by armed predation). But these clans had previously evolved complex and mutually beneficial systems of interdependent production. The ability of the otherwise very fragile Transitional Federal Government (TFG) of Somalia to survive in Baidoa until late 2006 suggests that viable inter-ethnic and inter-clan understandings were not impossible there. Thus these demographic and economic factors do not seem to us to have been absolutely determinative. 
We believe that other aspects of the political history of the south and centre are also important in explaining its instability and failure to build effective legitimacy from below. The military and business leaders there were so intent on displacing one another and on extracting the commercial and revenue benefits that would come from expansion that they neglected to consolidate their legitimacy at the base until it was too late.

The evidence for our proposition can be found by analysing Interpeace's superb compilation of the 93 local peace initiatives that were undertaken in the south and centre of Somalia between 1992 and 2007 (Oker and Habibullah 2010). These accounts demonstrate that the elders in these regions consistently have been and are deeply engaged in local governance and in the negotiation of conflicts between local lineages. Only in the early 1990s and then again as the Union of Islamic Courts (UIC) was gaining strength in the early 2000 s did these peace initiatives have international or regional government support. Whereas in the earlier and later periods claimants to regional authority were involved in 40 per cent of the local peace initiatives, between 1995 and 2004 they were engaged with only 32 per cent.

UN peacekeeping (UNOSOM) was involved in seven of the initiatives in the early 1990s but international support for local peace initiatives returned only after 2000 and then only nine times by a non-governmental organisation (Interpeace's Centre for Research and Dialogue), not directly from any donor or diplomatic organisation. Similarly there is very little (if any) evidence that elders were involved before 2000 in establishing and administering authority in the various regions of Somalia other than in Somaliland and Puntland, although they were central to all of the local peace initiatives. Prior to the inroads of the UIC and its offshoots (including al-Shabaab), control of the various regions was established by former officers of the army of Somalia (under Siad Barre) in alliance with businessmen who financed them and took advantage of the local monopolies over trade that they provided. These officer-business alliances appealed to sub-clan loyalties but did not seek validation from sub-clan elders or senior traditional leaders in establishing or executing their authority.
It is striking that none of the officer-business alliances in the centre and south of Somalia were able to survive - not even that of General Mohamed Farah Aideed, who for 15 years had control of as many regions as were core to Puntland or Somaliland and despite his group's outlasting the concerted efforts of US forces under UNOSOM-II to capture him. (He was subsequently killed in a battle but was succeeded by his ex-US Marine son.) Aideed was engaged in only two high-level regional peace initiatives, and Ali Mahdi, his major competitor, was involved in only two local ones. Politicians of some type were engaged in almost half of all the local peace initiatives, and claimants to regional authority were involved in 40 per cent. But this is a very low level of political engagement when one considers that the peace initiatives all concerned serious threats to order within a region's territory, thus showing considerable neglect of what Hobbes would have considered the core responsibility of the state - the security of its citizens. As we noted above, the largest degree of involvement by regional authorities was in the early and late periods, when there were military challenges to local control. In the interim period when outside threats dropped, regional leaders and their representatives concerned themselves with only 32 per cent of their local peace processes and thus squandered opportunities to enhance their legitimacy.

There is variation between the regions in the degree of involvement of political leaders in their peace initiatives. In Shabeele Hoose (Lower) and Hiraan there was none and instead all the peace efforts in the first were led by religious leaders and in the second by the symbolic traditional heads of lineages (isimo). On the other extreme, in Jubba Hoose, where control of the port of Kismaayo was at stake, there were 19 initiatives in the early and late periods of conflict and claimants to regional authority were involved in 58 per cent. Similarly 92 per cent of the peace processes in Gedo involved the regional leadership. It probably is no coincidence that Gedo is the region out of which the Jubba Valley Alliance (JVA) was able to launch the takeover of the two Jubba regions (and Kismaayo) in 2001. The JVA then engaged in a spurt of 13 local peace initiatives in these two regions after 2005, but by this time the UIC had already gained considerable strength in the area. 
Puntland is similar to the south in having grown out of the initiative of a warlord who had business support, but in its case assemblies of elders also were involved intensively and extensively in regional governance and it twice even supported the peace initiatives of elders on its southern periphery. Both in Somaliland and Puntland these consultations seem to have given the new structures of authority a legitimacy and durability that were lacking in the centre and south.

Of course ultimately political Islam came to be the dominant contestant for control in the centre and south. It has shown the legitimacy and durability that the officer-business alliances lacked. The 2006 attempt of Ethiopia (with US support) to dislodge the UIC ultimately was unsuccessful. (When Ethiopia abandoned its attempt, the more moderate Islamists took leadership of the TFG but the radical al-Shabaab announced an alliance with al-Qaeda. It may be that the legitimacy and durability of the radical Islamists in their areas are not as solid as Somaliland and Puntland are in theirs, but this is hard to judge since the international environment has been hostile to the Islamists and more accepting of the two polities in the north.) It also is striking that in the cases in which external military forces have been able to dislodge radical Islamists in district capitals, the Islamists have nonetheless remained effectively in control in the rural areas. All of this suggests that political Islam is able to establish deeper roots in the social structures of the Somalis than military-business alliances can - unless the latter have involved elders and traditional senior leaders. During the period in which the warlords were neglecting the peace initiatives of elders in their areas the Muslim Sharia courts were engaged in their communities in the resolution of family and commercial disputes and we find them having been involved with 24 local peace initiatives (26 per cent of the total). Note too that in the middle period when the Islamists were consolidating for a challenge to the secular authorities, their involvement rose to 36 per cent. Variation within the south is revealing as well. Islamic religious leaders participated in all the initiatives in the Middle (Dhexe) and Lower (Hoose) Shabeele Regions and 43 per cent of those in Bay and Bakool. The Hawiye clan dominates in the former two and the Rahanweyn in the latter pair and these are the two clans that now show most allegiance to al-Shabaab. The early presence of Islamic peace efforts in Bay Region is particularly striking, as the TFG was headquartered there until 2006. Despite being dependent on Bay Region, the TFG leaders and the regional authorities there showed the lowest involvement (14 per cent) with local peace initiatives of any other area in the south and centre of Somalia.

The preceding analysis has important implications for the TFG and the prospects for its successor. The TFG structure of representation has been based on the cooptation of 'warlords' and traditional leaders whom they in turn have co-opted. It lacks the deeper roots in Somali society provided by political Islam's incorporation of Imams and by the extensive consultation with a fuller array of elders that Somaliland and Puntland undertook.

\section{Conclusions}

The economics, demographics and conflicts in the south and centre of Somalia all were such as to make the involvement of elders and other local structures in shaping and legitimating regional governance more difficult. Elders, sub-clan leaders and religious leaders were not missing, however. They were engaged in numerous initiatives to resolve and bring peace to local disputes.

Occasionally the international community or regional warlords and politicians supported these local initiatives, but usually they were preoccupied with reconstituting a national government and who would dominate it. They focused on fighting, negotiating with and co-opting the militia leaders and businessmen who put themselves in contest for national office, and for the international resources that could be expected to flow through a government of Somalia once it was properly constituted.

The consequence was that possibilities for consolidating regional governments and legitimating them with their populations were neglected. After the UN retreated from its early effort to build decentralised regional governments up into a national federation, communities were left to govern themselves.

This gap in local governance was taken up not only by sub-clan and other traditional structures but increasingly by Sharia courts as well. By the time the warlords contesting for national power 
realised that their real opponents were not one another but the proponents of political Islam the opportunities to build a counter from below were lost in most of the country.

It may be that sub-clan elders and lineage leaders will be able to join with more moderate Islamists to defeat the radical versions of political Islam in much, and maybe all, of Somalia. The moral of the experience of the Somalis is clear, however. In a conflict country, the social contract that exists

\section{Notes}

1 Diya groups are made up of about 100 adult males in a sub-lineage who exact and pay compensation for torts committed against and by group members (Lewis 1999 [1961]). Such

\section{References}

Bradbury, M. (2008) Becoming Somaliland, London: Progressio

Gundel, J. and Dharbaxo, A.A.O. (2006) The Predicament of the 'Oday': The Role of Traditional Structures in Security, Rights, Law and Development in Somalia, Nairobi: Danish Refugee Council, Novib-Oxfam

Hoehne, M.V. (2011) No Easy Way Out: Traditional Authorities in Somaliland and the Limits of Hybrid Political Orders, DIIS Working Paper,

Copenhagen: Danish Institute for International Studies: 32

Leonard, D.K. and Samantar, M.S. (2011) 'What Does the Somali Experience Teach Us about between citizens and their local governance structures not only does not disappear but becomes much more critical to the security of those at the bottom. A primary part of post-conflict reconstruction must be rebuilding the social contract between community governance structures and national ones. In some circumstances local governance may need to be reformed; not everything that is 'traditional' enjoys the support of its constituents. But citizens will rebuild and revalidate the state only from the bottom-up.

use of ascriptive ties for security and advantage seems common when civil war forces a breakdown in formal governance structures.

2 See appendix for further detail about these regions.

the Social Contract and the State?', Development and Change 42.2: 559-84

Lewis, I.M. (1999 [1961]) A Pastoral Democracy, Oxford, Muenster-Hamburg: James Currey Publishers, International African Institute

Mamdani, M. (1996) Citizen and Subject: Contemporary Africa and the Legacy of Late Colonialism, Princeton: Princeton University Press

Mohamed, H.A. and Nur, A.A.M. (2008) The Puntland Experience: A Bottom-up Approach to Peace and State Building, Nairobi: Interpeace

Oker, I.A.A. and Habibullah, S.a.I.H. (2010)

Community-based Peace Processes in South-Central Somalia, Nairobi: Interpeace

Appendix Region-by-region histories of political control in the south and centre of Somalia

\section{Mohamed Samantar}

The earliest resistance to Siad Barre's government came from groups in the north of Somalia - the Somali Salvation Democratic Front (SSDF, 1978, Darood clan and Majeerteen sub-clan) and the Somali National Movement (SNM, 1981, Isaaq clan), which eventually emerged as the dominant forces in Somaliland and Puntland, respectively.

In the south and centre of Somalia, groups of army officers struggled to displace and then replace Barre, financed by businessmen seeking monopolistic control of trade (ports, towns and routes). These 'parties' were not originally organised along clan lines, but in response to Hawiye clan efforts others gradually responded by clan affiliation as well.

Jubba Hoose (Lower)

This region includes the important port of Kismaayo. Initially it was controlled by a group of army officers who had been close to Siad Barre and were primarily of the Ogaden and Harti sub-clans of the Darood clan - the Somali Patriotic Movement (SPM, 1989).

At first General Mohamed Said Hersi 'Morgan', who was a son-in-law of Barre, was a part of this group, even though his personal sub-sub-clan was Majeerteen (Harti). Ultimately 
'Morgan' broke with the Ogadenis in the SPM, who became the Somali National Front (SNF, 1991), and his Harti branch of the SPM displaced both the Ogadenis from Afmadow and the Somali National Alliance (SNA, Mohamed Farah Aideed, Habar Gidir of Hawiye, 1992) from Kismaayo. Morgan and Colonel Ahmed Omar Jees retained control of Kismaayo through 2001. Morgan's move against Aideed as well as Jees's realignment from the latter to the former occurred in the context of the UNOSOM-II campaign to capture and defeat Aideed.

From 2001 to 2006 the Jubba Valley Alliance (JVA, Marehan of Darood and Habar Gidir of Hawiye) under Colonel Barre Hiiraale had control with the support of the President of the Transitional National Government (TNG).

In 2006 the UIC took control. (One of the UIC leaders, who eventually became leader of the [radical Islamist] al-Shabaab faction, was Ahmed Godane. Although he is Isaaq from Hargeysa, the dominant clan in al-Shabaab is Hawiye.) For a short period after 2007 Ethiopian troops occupied Kismaayo but they were never able to displace the Islamists from the rural areas. Thus when Ethiopia withdrew al-Shabaab retook the city, which as of August 2012, has not yet been taken by the Kenyans (who have now joined the African Union forces in support of the Transitional Federal Government, TFG).

Politicians were involved in UNOSOM's efforts in the early 1990s to broker peace between the parties but returned to peace initiatives again only between 2004 and 2006 as the Jubba Valley Alliance was struggling to counter the UIC.

\section{Jubba Dhexe (Middle)}

When Morgan and the SPM controlled Jubba Hoose they also had control in Dhexe, as Barre Hiiraale and the JVA did after them and then the Islamic Courts Union. There was no religious involvement with the local peace initiatives. Politicians were involved in half of the mediation exercises.

\section{Gedo}

This is a Marehan (of the Darood clan) area and thus of Siad Barre's sub-clan. Its SNF retained control, and then in 2001 under Colonel Barre Hiiraale and the JVA it was able to extend its control first to Jubba Dhexe and then Jubba Hoose as well.

The JVA was displaced in all its areas by the UIC in 2006.

Of the 12 local peace initiatives politicians were involved in 11 (with four coming after 2005) and Muslim leaders in two.

\section{Mogadishu}

As the prize port and capital, this city, between the two Shabeele regions, was the site of the most intensive and longest violent conflicts. The city came to be divided by a 'Green Line', with Mohamed Farah Aideed (and later, his son, Hussein) and the Somali National Alliance (SNA, 1992, Habar Gidir of Hawiye) controlling the south and Ali Mahdi and his faction of the United Somali Congress (USC, 1989, Abgaal and Murasade of Hawiye) the north, until the TFG was able to establish a foothold in 2007 with the support of troops from Burundi and Uganda.

\section{Shabeele Hoose (Lower)}

From 1991 to 2006 the region was controlled by the Southern Somali National Movement (SSNM) party of the Biyomaal sub-clan of the Dir, but in alliance with the USC-Somali National Alliance (SNA, 1992, Habar Gidir of Hawiye; called SRRG after 2001) of Farah Aideed, which had control of Mogadishu south of the 'Green Line'. In 2006 the region 
became UIC, then Ethiopian, then al-Shabaab. All of the region's peace initiatives involved religious leaders and none involved politicians.

\section{Shabeele Dhexe (Middle)}

Extending north from Mogadishu, this region was also controlled by the SNA and Ali Mahdi, until it was captured by UIC in 2006. It is now under al-Shabaab. All five of its peace initiatives involved religious leaders and Ali Mahdi played a role in two.

\section{Bay and Bakool}

These two regions are the core of crop production in Somalia and also are the area of the sedentary Rahanweyn clan (Rahanweyn Resistance Army, RRA). The two regions were briefly controlled by Farah Aideed's SNA but after he was displaced the two became one of few areas under the direct control of the TNG, until 2006 when it was overthrown by the UIC. The RRA was the one party in the region that had some involvement of elders. Six of the 14 peace initiatives involved religious leaders and four involved politicians. The Rahanweyn clan (with the Hawiye) have become prime supporters of al-Shabaab.

\section{Hiraan}

This area was allied with Ali Mahdi and the USC in Mogadishu and also was part of the TNG. In this region the group exclusively comprised former military officers, without business support and was dominated by the Hawaadle sub-clan of the Hawiye. They were supported by Ethiopia and when Ethiopian forces withdrew the non-Hawaadle minorities joined al-Shabaab and overthrew them. Ethiopia has now returned to Beledweyne and re-established the Hawaadle USG in the town, but the rural areas are still al-Shabaab. There was no support by regional authorities in Hiraan for community peace initiatives.

\section{Galguduud}

The region is predominately Habar Gidir of Hawiye and thus support Farah Aideed and the USC. There is a minority of Marehan (Darood) in the region, but no more than a few villages supported the SNF. The region fell to the UIC in 2006 but in the dissolution of that movement it became Al Sunna wal Jamah, which is more moderate and supports the TFG.

\section{Mudug}

This region has more internal divisions than any other, save Mogadishu. The area north of Gaalkacyo is Majeerteen (of Darood), allied with the SSDF and is a secure part of Puntland. The south is Habar Gidir (of Hawiye), supported the SNA of Farah Aideed, and is now controlled by the more moderate Islamists of Al Sunnah wal Jamah. However, the south-east of Mudug is embroiled in a struggle for control over the resources generated by piracy and is under secular sub-sub-clans of the Habar Gidir, the Sacad and (in Hobyo) the Saleeman.

This is the one area in which Aideed was involved in a peace initiative, while Puntland engaged in three of the eight.

Sources for this appendix (beyond the knowledge of the author) are:

Lewis (1999 [1961]); Mohamed and Nur (2008); http://en.wikipedia.org/wiki/Factions_in_ the_Somali_Civil_War (accessed 10 March 2012); http://en.wikipedia.org/wiki/Demographics _of_Somalia\#Clan_structure (accessed 21 April 2012); http://en.wikipedia.org/wiki/United _Nations_Operation_in_Somalia_II (accessed 28 April 2012). 